\title{
The Spectre and the Empire: Reading B. M. Croker's Ghost Stories
}

\section{Debarghya Ganguli}

\begin{abstract}
B. M. Croker's successfully incorporated the gothic, the horror, the spectre, identity and the empire in her two short stories, "To Let" and "The Dâk Bungalow at Dakor" among many others. She utilised her experiences in India to highlight the troubled relationship between the coloniser and the colonised while focusing on the two worlds from her own perspective of an unaccommodated woman in a colonial scene. The horror of the ghost thus functions on different historical, political, social and psychological levels in her fiction exploring and exposing the relationship of the empire with the natives. Moreover, Croker's female narrator also opens up a series of questions regarding gender, identity, foreignness and trauma. The introduction of a foreign ghost in a native setting further complicates the relationships which Croker works on in her narration. Set against the backdrop of a socio-historical parameter, her stories, thus become interesting documentations of the functioning principles of the empire and the spectral dimension in the Indian context. This paper proposes to address these intersections and arrive at a deeper understanding of the horror story in the colonial context.
\end{abstract}

Keywords: Horror, Spectrality, Foreignness, Trauma, Empire.

\section{Introduction}

Bithia Mary Croker (1849 - 1920) represented her experience of living in India and Burma for fourteen years $(1877$ - 1892) as the wife of a lieutenant colonel in the Royal Scots and Munster Fusiliers in her writing. In To Let (1893), she offers two stories, 'To Let' and 'The Dak Bungalow at Dakor' which present the spectral element, which she later recaptures in 'Number Ninety'. Along with Alice Perrin and Rudyard Kipling, she was writing about ghost sightings in a foreign land. However, these stories do not simply represent hauntings of the dead, but are replete with colonial overtones. Ghost stories and the horror these entail, have been read from various perspectives.

While Julia Briggs has located these as a special category of the gothic, based on the structural hierarchy, David Punter and Avery Gordon have traced the roots of horror in Capitalism and social oppression respectively. Srdjan Smajic has resorted to the contemporary Victorian theories of seeing as a method of interpreting the spectral. From Freud's uncanny to Foucault's madness, delusion, illusion and hallucination have been considered as multiple ways of analyzing the sightings. However, Andrew Smith and Simon Hay focus on the implications of horror in the colonial context and suggest a mimicry/mockery paradigm following Homi K. Bhabha and a hierarchy of three different styles of fiction. 
This study proposes to explore the six layers in which horror and spectrality functioned in the colonial Indian discourse, which has attracted meagre attention. The texts in consideration are constructed primarily from the Victorian perspectives of ghost sighting, and thus critique the prevalent theories of spectral presences. Secondly, the ghost also becomes an occasion for the critique of the Empire, seen from both the perspectives of the Coloniser and the Colonised. Thirdly, the gendered critique of the British imperial presence can be clearly traced in the stories. Fourthly, these stories serve as commentaries on the 'uncanny' nature of the ghost as an experience of anxiety reflected in the coloniser and colonised relationship. This can explain why the ghost stories, involving fear, trauma, and an encounter with the "real"-ity of the ghost, lead to a foreclosure of language, and the ghost, like the empire, leads to a sort of disillusionment with the very symbolic and imaginary discourse of both. Thus, this study shall also focus on the psychoanalytical implications of these stories. Fifthly, located in the historical context of India, these stories entail a premise of the spectre and horror as a site of identity. finally, this study shall try to locate the cultural identity of the subjects through the lens of the discourse of horror in a colonial context. This paper shall, for obvious reasons, only focus on "The Dâk Bungalow at Dakor".

\section{The Ghost and the Empire}

The Victorian era witnessed a massive shift in the domain of both the narratives concerning ghosts and the narratives of ghost sightings. The gothic was already a well-established genre. Moreover, with the novels of Horace Walpole, Anne Radcliffe and Matthew Lewis, the medievalism of the gothic as a genre shifted from an aesthetic register to one of horror. In the 1830s Sir Walter Scott in his Letters on Demonology and Witchcraft (1830) and David Brewster, in his Letters on Natural Magic (1832) argued that ghost sightings are often products of optical illusion. Our sight often deceives us about, shapes, nature and even existence of objects. This optical theory held an important influence on the fiction of Nineteenth Century. Towards the end of the century this notion was further complicated by the questions of what we see and we see it. In this regard, Thomas Reid, in his Essays on the Intellectual Powers of Man (1969) opines that the sense receptors simply function as conduits of sense data. They can neither ascertain, nor perceive the nature of the nature of the thing observed. Hence, it is only natural that too much reliance on the senses might end up in a misconception about the things observed. The same line of argument can also be traced back to George Berkeley, when he suggests, "visible objects are only in the mind" and in no way "suggest ought external, whether distance or magnitude, otherwise than by habitual connexion as words do things" in his An Essay Towards a New Theory of Vision (Berkeley, 1975, p.31). Thus, it can already be determined that the Victorian age was looking at the phenomenon of the ghost as both an optical illusion and as a projection of one's own psychological condition. This called into question both the nature and existence of the ghost and also the authenticity of the narrative of the one who claims to have seen them. The witnesses seem to see what they think is the ghost became the norm of the day instead of the witness has seen the ghost and therefore the ghost exists. This movement from a form of Coleridgean "Suspension of disbelief" to a deeper psychological and scientific inquiry into the nature, existence and the mental state of the ghost, along with the language of narration of the event marked a paradigmatic shift in the Victorian ghost story genre.

Located in the colonial context the spectral nature of the stories alters to a great degree, as these propose to project the tension between the two races. The tension is often linguistic, rather than narrative. In his book, The Location of Culture (1994), Homi K. Bhabha traces this linguistic bifurcation and tension, "The discourse of post-Enlightenment 
English colonialism often speaks in a tongue that is forked, not false" (Bhabha, 1994, p.85). This bifurcation often leads to a parody according to Bhabha, as it constantly employs a dialectic between mimicry and mockery,

Mimicry is thus the sign of a double articulation; a complex strategy of reform, regulation and discipline, which 'appropriates' the Other as it visualizes power. Mimicry is also the sign of the inappropriate; however, a difference or recalcitrance which coheres the dominant strategic function of colonial power, intensifies surveillance, and poses an immanent threat to both 'normalized' knowledges and disciplinary powers. (Bhabha, 1994, p.86)

This dialogic relationship often functions as a contrapuntal narrative to the sanctioned transgressions offered by the Bakhtinian discourse of the carnivalesque. Moreover, the tension gets further intensified by the taxonomy of the spectral narratives, as Simon Hay elucidates in his book, A History of the Modern British Ghost Story (2011). The stories were broadly classified in three types. In the first case, the native superstitions are challenged by the white rationalism, thus exposing the native foolishness. In the second type, the native spirits cause problems and the white man resolves them. And finally, the colonial space is invaded by white ghosts and the imperial occupation is historically legitimised.

\subsection{Croker's Spectral Narrative}

Among the three ghost stories of Croker two, viz. "The Dâk Bungalow at Dakor" and "To Let", are located in colonial India, and present an English ghost in a colonial setting. In the former, Croker establishes a microcosm of England in the native Indian locale, in a town called 'Karwassa'. It is a civilised town with a station that resembled "an oasis of civilization, amid leagues and leagues of surrounding forest and jungle" (Croker, 2005, p. 96). The narrator, Nellie Loyd, the wife of an English forest officer, represents the mood of Englishness and sets the tone of the story, where we see how a single geographical locale harbours two worlds simultaneously. From her privileged perspective of the coloniser master she appreciates the western prerogatives that Karwassa has to offer. The Anglo-Indian nature of the town is established with a prominent presence of the post office, public gardens, tennis courts, and a church. Nellie is attuned to the "ice machine" (Croker, 2005, p. 96). which brings vestiges of the English "season" (Croker, 2005, p. 96). in the Indian clime, the routine of "tennis at daybreak, moonlight picnics, whist-parties," and "little dinners" (Croker, 2005, p. 96). The plot unravels when Nellie accompanies her friend Mrs. Julia Goodchild, the wife of a British police officer to meet their husbands on Christmas from Karwassa to the distant town of Chanda despite the warnings of Mrs. Duff. Croker is quick to show the generation gap in the story through the subtle hints of attitude. Mrs. Duff belongs to the older generation, who take into consideration the local superstitions and pay heed to the stories. She seldom leaves Karwassa and is content with the little slice of England offered to her in the locality. But Nellie and Julia are the young generation, impetuous and in search of some adventure in the enchanting orient. However, it Mrs. Duff who sets the tone of the spectral which is central to the narrative of Croker, "Chanda-Chanda . . . Isn't there some queer story about a bungalow near there - that is unhealthy — or haunted or something?" (Croker, 2005, p. 97). But Julia assures her that it is more likely to be in a want of repair than be haunted. Moreover, she does not rule out the taxing effect that the journey might have on the traveller's mind and body. This is one of the many instances where Croker poignantly pitches reason against superstition, fact against fiction and the seen against the heard. Her constant doubts of the received narratives also help us to probe further into the coloniser's disbelief into the narrative of the colonised. Since, the nature of the ghost is still unknown to the narrator, she inscribes it to some local fiction. 
The Englishness that Nellie and Julia are so comfortable with soon is challenged despite their well-prepared journey. On the third day of their journey, as soon as they turn to the old Jubblepur road, the scenario changes drastically. The oxen that carried their cart soon become incapable of supporting their journey and Abdul, the Indian servant is given the task to look for new arrangements for the travel. The two women start walking with the resolve to cross even sixteen miles by foot rather than waiting the night at some unknown Indian locale. Croker points out the tension between the coloniser and colonised and men and women through the reactions of the native Indian villagers,

the few people we encountered driving their primitive little carts stared hard at us in utter stupefaction, as well they might - two mem sahibs trudging along, with no escort except a panting white dog. The insolent crows and lazy blue buffalos all gazed at us in undisguised amazement as we wended our way through this monotonous and melancholy scene. (Croker, 2005, p. 99-100)

It is as if Nellie and Julia forgot that a mem sahib has got to act like a mem sahib. The gendered response to the ladies did not escape the periphery of mem sahibs either. Croker is quick to subtly suggest it at certain junctures of the narrative.

At the next village of Dakor, the duo decides to stay at the Dâk Bungalow. However, an old Indian woman, a counterpart of the British Mrs. Duff, shakes her hand in a warning manner as they approach the building. The gesture is a concern for human life which is tethered by both linguistic barrier and colonial hierarchy. Croker notices how the bungalow remained uncared for and offers subtle hints towards the changing political dynamics between England and India,

we discovered that the drive was as grass-grown as a field; jungle grew up to the back of the house, heavy wooden shutters closed all the windows, and the door was locked. There was a forlorn, desolate, dismal appearance about the place; it looked as if it had not been visited for years. (Croker, 2005, p. 100-101)

Melissa Edmundson, in her essay, "Bithia Mary Croker and the Ghosts of India" (2010), suggests, "Croker also carefully positions her story around an architectural element of the Indian landscape that held symbolic significance for both the English and Indians after the 1857 Mutiny" (Edmundson, 2010, p. 95-96). Citing Margaret MacMillan and Iris Portal, she draws real life parallels between the description given by Croker and the actual Indian situation. Macmillan quotes in her book, Women of the Raj (1988) the inflammatory remarks that were often found on such bungalow walls, "Revenge your slaughtered countrywomen! To - with the bloody Sepoys!" (Macmillan, 1988, p. 102). On the other hand, Portal, a member of a civil service family, living in Meerut in twentieth century reminisces,

There was one bungalow nearby where they had to take their beds out into the garden, not only for the heat but because things happened, like doors blowing open when there was no wind. Dogs would never stay in the house, and it was emphatically haunted. They all felt it and they all hated it, and that was one of the Mutiny bungalows with a plaque on it. (MacMillan, 1988, p. 103)

In Croker's tale, the suspicious looking caretaker is not at all willing to let them enter the bungalow. When they break the lock and enter and settle down, Croker's narrative becomes disturbingly racial in its attitude. Through the window the women see the 
countenance of the caretaker,

It was the face of some malicious animal, more than the face of a man, that glowered out beneath his filthy red turban. His eyes glared and rolled as if they would leave their sockets; his teeth were fangs, like dogs' teeth, and stood out almost perpendicularly from his hideous mouth. He surveyed us for a few seconds in savage silence, and then melted away into the surrounding darkness as suddenly as he appeared. (Croker, 2005, p. 103)

The abject discourse which she employs, fortifies the cultural and racial hierarchy. While Nellie resorts to comparing him with a dog, Julia compares him with the Chesire Cat from Alice in Wonderland, another tale where a visitor encounters a strange land which disorients her. However, the animal imagery persists in their description. In comparison, Abdul sleeps in the veranda whereas the women sleep in the private space of the bolted room, directly establishing the dynamics of a master/slave dialectic.

\subsection{History}

But, if we probe deeper, we can see the dwindling English grasp on India in a greater scale than the simple disgust towards the natives through the animal imagery or the dilapidation of the bungalow, and the nuanced usage of horror that serves as a bridge between the master and the slaves. Sekhar Bandyopadhyay, in his book From Plassey to Partition: A History of Modern India (2004) traces the long line of historical thread that was changing the Indian scene rapidly. In 1867, the government increased the revenue rates "on grounds of extension of cultivation and rise in agricultural prices" (Bandyopadhyay, 2004, p. 196). This led to a long series of peasant revolts in agrarian India. Bandyopadhyay notes,

... in the second half of the nineteenth century . . occurrences of peasant protests against moneylenders were quite common throughout India, as colonial rule had significantly altered the relationship between the two groups in the political economy of the village. And everywhere we find similar patterns of peasant behaviour . . . (Bandyopadhyay, 2004, p. 198)

This had long lasting impact of pre-Indian National Congress politics, as it was arguably the first step towards the emergence of Indian national identity. Such an uproar, coincidentally took place in Rajasthan, in 1891, the very year when these two stories were published. The bungalow, consequently, captures the two worlds that resided in India, the past glory of the empire and its present decay, and the poor India, marginalised by the coloniser against the rich India, promoted by the coloniser to ultimately plunder. After 1857, the British Government sought to reinstate the wealthy landlords, the zamindars, to ensure the allegiance of the subjects and smoothly run the local governance at their expense. In 1861, when the Indian Councils Act allowed a limited representation by the Indians in legislative councils, the British Indian Association of Calcutta, the Madras Native Association and the Bombay Association pleaded for the cause of the landed gentry. They wanted to gain more from their connection with the British. Thus, India was already divided between the haves and have nots. But the political and economic situation in Europe also changed to a great extent during this time.

When Karl Marx theorized 'The Fetishism of Commodities.' he spoke about spectral terms in Capital (1977). Citing the example of a table, he suggests, "It not only stands with its feet on the ground, but, in relation to all other commodities, it stands on its head, and evolves out of its wooden brain grotesque ideas" (Marx, 1977, p. 435). Chris Baldick 
develops upon Marx's gothic argot in his book, In Frankenstein's Shadow: Myth, Monstrosity and Nineteenth-Century Writing (1987), where he expands the 'grotesque ideas' that Marx was talking about, "Throughout Marx's writing. . . ghosts, vampires, ghouls, werewolves, alchemists, and reanimated corpses continue to haunt the bourgeois world, for all its sober and sceptical virtues" (Baldick, 1987, p. 121). The nineteenth century economic processes have been aptly termed by Tricia Lootens in 'Fear of Furniture: Commodity Gothicism and the Teaching of Victorian Literature', as, 'Commodity Gothicism'. Andrew Smith suggests in his book, The Ghost Story, 1840-1920: A Cultural History (2010),

She argues that the image of the ghost is frequently used in order to draw attention to the occluded presence of labour within the production of commodities. She also raises questions about the role that consumption plays in this, as it too brings into being objects that are transformed subjectivities and desires, and thus have a key role in conjuring the ghost. (Smith, 2010, p. 14)

Curiously enough, Croker's narrative hangs in the limbo between the two cultures and allows us to view them in respect to each other.

\subsection{The sighting}

In the room where they decided to spend the night, they find the vestiges of some former traveller's belongings. At night Nellie is startled by the presence of a figure in the room, who pays no notice to the two women sleeping. Croker leaves the reader wondering about the obvious peculiarity of the fact that the doors were bolted and it would have been impossible for the stranger to enter the room. She rather focuses on the nature of uncanny and shock of the encounter that Nellie suffers. He sits at the table, writing a letter, and Nellie notices that among his belongings is a gun case. But even in this encounter of strange import, Nellie is more comfortable with an English stranger rather than a native Indian,

He was young and good looking, but very, very pale; possibly he had just recovered from some long illness. I could not see his eyes, they were bent upon the paper before him; his hands, I noticed, were well shaped, white, and very thin. He wore a signetring on the third finger of the left hand, and was dressed with a care and finish not often met with in the jungle. (Croker, 2005, p. 103-04)

Avery F. Gordon suggests in Ghostly matters: Haunting and the sociological imagination (2008)

I used the term haunting to describe those singular yet repetitive instances when home becomes unfamiliar, when your bearings on the world lose direction, when the overand-done-with comes alive, when what's been in your blind spot comes into view. Haunting raises spectres, and it alters the experience of being in time, the way we separate the past, the present, and the future (Gordon, 2008, p. xvi)

By offering a Freudian study, she arrives at a curious inference which seems to coincide with that of Croker, "The 'reality-testing' that we might want to perform in the face of hauntings must first of all admit those hauntings as real" (Gordon, 2008, p. 53). In this context Stephen Frosh offers quite an interesting insight in his "Hauntings: Psychoanalysis and Ghostly Transmission", 
From past to future, from subject to other, psychoanalysis practices a disturbance of rational communication. The dimensions here are both 'vertical' (time) and 'horizontal' (space). The vertical refers to what gets transmitted from one time period to another, from one generation to another, so that those who have no direct experience of an event may nevertheless be affected by it. Much of the scholarship and clinical writing that has attended to this vertical dimension of haunting has been concerned with the intergenerational transmission of trauma, and this of course is vital work. But it has other elements too, to which Freud was attuned, notably questions of the generational continuity of ethnic and religious identity. In more contemporary language, it is also what underpins much postcolonial critique: how the societies of today carry with them the active ghosts of previous times. (Frosh, 2012, p. 242)

By placing the ghost in the centre of the room Croker significantly marks the ghost as central to Nellie's consciousness. She also questions the way in which the reader perceives the ghost. Read in the light of the British readers whom she was addressing with their preconceived notions of India and the orient, the ghost thus becomes an important tool in interrogating and assimilating the readers and positioning their responses from a cultural perspective. Melissa Edmundson believes,

By having ghosts who are British and India in her stories, Croker calls into question this idea of marginality. In their dependence on the Indian natives and their presence as a minority in India, the British were, in many ways, marginal, though they tried not to think or act this way in public. By moving British ghosts to the "center" of her supernatural tales, Croker is implicitly commenting on the dangerous instability of colony. The ghost's influence thus extends beyond the local, beyond the specific site of empire. (Edmundson, 2010, p. 97)

The issue of this precarious position of a volatile marginality and the instability of the colony thus become key issues of Croker's narrative. She hastens the pace of the narrative deliberately over here to create a sense of immediacy and does not forestall the premonition any further. To her surprise, Nellie witnesses the murder of the Englishman by his servant and the caretaker. Right at the moment of death the apparition acknowledges her with a "a sad, strange look! a look of appeal" (Croker, 2005, p. 104). The narrative has a cinematographic character with Croker, and instead of hiding the event of the spectral sighting, she openly talks about it in ample detail. This has both a familiarising impact and an alienating effect, as the ghost is at once seen and the disbelief is yet not dispelled as it is seen by the narrator and not everyone else, and the description is narrated in language. When Nellie wakes up, it is already dawn. In her bewilderment, she confesses the entire event to Julia, though it felt like her tongue was paralysed. The lack of language on her part and what and how she narrated those events to Julia, are left suspended. This narrative gap is interesting as it helps us probe deeper into Nellie's trauma. In his Seminar III, Jacques Lacan suggests, "It is insofar as [the patient] has not acquired ... the [symbolic] Other [language with its underlying structure] that he encounters the purely imaginary other. This other negates him, literally kills him" (Fink, 1997, p. 236). Bruce Fink clarifies in his A Clinical Introduction to Lacanian Psychoanlysis (1997),

Nevertheless, Lacan reminds us that just because a patient complains that someone is trying to do him or her harm, we cannot automatically assume that the patient is psychotic: the complaint may be true, or it may be so outrageous as to be obviously false, but often it is not very easy to tell. In this context, Lacan once again reiterates that in order to be sure the patient is suffering from psychosis, "there must be language disturbances" (Seminar III,106). (Fink, 1997, p. 96) 
But, in her rational spirit, Julia breaks it down to gibberish, "'Ghosts! murders! walk to Chanda!' she echoed scornfully" (Croker, 2005, p. 105). At once, we realise the discrepancy between the two experiences of the otherwise friends who share a common ground. It is this sense of alienation that the horror of the gothic or spectral that helps us probe further into the identity of wo/man in society. Dr. Garret Merriam, in his YouTube lecture entitled, "The Philosophy of Horror", suggests, "Horror is the blanket we throw over the invisible man, giving him shape." For Julia, Nellie has had a nightmare due to indigestion. Croker enacts a Chaucerian echo of "The Nun's Priest's Tale", and consequently none believes in the emanation till the ghost actually appears like Russell, though here the apparition does not come with the intent of harming.

Nellie refuses to spend the second night in the accursed bungalow. But Julia is insistent and she alone spends the night in the room to be a witness to the same event. From a traveller's register and a local village woman they come to know about the bungalow being last visited seven years ago and that it is haunted by "devils" (Croker, 2005, p. 106). In contrast to the specificity of Nellie's encounter, the village woman remark of the devil falls short and is rathe ambiguous and misleading. The traditional association of malignant spirits with the diabolic nature is subverted here as it is the living who act more out of malice than the dead. Croker was more intent on a well-knit story, and hence focuses on retribution and redemption. As their husbands appear from Chanda, despite the initial disbelief the body is found and given proper burial, though the caretaker fled and was mysteriously believed to be dead later. The story closes at a dinner where the two women hide the events of the two nights at Dakor, though Julia comments, "I shall never, never forget last night as long as I live" (106)

\subsection{Identity}

"The Dâk Bungalow at Dakor" is multi-layered in its narrative scope. It interrogates the assumption that the lesser-known women's writing of the empire is a mere "historical curiosity" (Edmundson, 2010, p. 103), as Edmundson points out. In her essay, "Burning Down the Master's (Prison)-House: Revolution and Revelation in Colonial and Postcolonial Female Gothic," Carol Margaret Davison points out the dual problem of female gothic in the empire gothic. It simultaneously presents "the manor/Great House" as a site of the female and also as the root of the volatile relationship between the coloniser and the colonised, as "a site of historical and cultural, conscious and unconscious, collisions and collusions" (Davison, 2003, p. 138). Croker's narrator is a perennial outsider and her attitude towards the natives merely mirrors the horror of social and political anxiety. Jenny Sharpe in Allegories of Empire (1993) suggests that Julia is representative of "notorious female figure" (Sharpe, 1993, p. 91), a kind of stock character popular with post Sepoy Mutiny women's fiction. In an October 1886 article, J.E. Dawson in the Calcutta Review mentions, "Each Englishwoman, in her own Bungalow, is the centre of an influence, and the cynosure of an argus-eyed criticism, even to her most insignificant acts, to which her English life offers no parallel" (Dawson, 1886, p. 363). Therefore, the "memsahib" was always a central concern in the colonial discourse. She is neither at the helm, where the male coloniser reigns and rules, nor is she a part of the colonised subject. She is rather the unaccommodated woman who resides in a perennial anxiety regarding her position in society.

The trauma of the sighting amplifies the personal, political and social anxiety in Croker's narrative. If understood in Freudian terms, this is an encounter, as Gordon suggests, with 
"what the concept of the unconscious represses: the reality of being haunted by worldly contacts" (Gordon, 2008, p. 54). However, this "uncanny foreignness" to borrow Julia Kristeva's term from Strangers to Ourselves (1991), is to acknowledge that "we are our own foreigners, we are divided" (Kristeva, 1991, p. 181). Therefore, the strangeness is both external and internal. The question, hence, shifts from whether the ghost is real, to what we make of the ghost. Even if we consider for a moment that the ghost is an illusion, delusion or hallucination, it is still represented in language.

\subsection{Language}

Ghost stories involve fear. Fear involves trauma, more specifically the trauma of encountering the real, which in Lacanian discourse is a disillusionment with symbolic and imaginary. There are two sets of aporia functioning at the centre of Croker's ghost story. Visualization of a ghost can only be narrated in language, and no language can define the spectral. Moreover, since the ghost is not a living being, but simply has a human semblance, paradoxically the ghost can only be represented in human terms. Thus, a foreclosure of language occurs. Hallucination involves visuals, and visuals involve a foreclosure of language, a violation of the symbolic. But interestingly hallucination is also linguistic, as without language it cannot be represented. For Jacques Lacan, the real entails a total suspension of the symbolic and imaginary. Therefore, encounter with real is an encounter with anxiety. The subject is split between something and nothing. Hence, what is foreclosed in the symbolic is manifested in the real.

\section{Conclusion}

As the study has already shown, the indeterminacy and polyvocal nature of the ghost and the narrative itself raise more questions than they resolve. The stories are products of a dissemination from people to people as is common with oral literature concerning the improbable and supernatural. Rather than unravelling the true nature of the ghost, this study solely focused on what are the implications of the ghost in a colonial discourse. Along with what we are afraid of, this study focused on why and we are afraid of something that precariously maintains a dual state of spectral/uncanny.

\section{References}

Croker, Bithia Mary. (2005). The Dâk Bungalow at Dakor. In Roger Luckhurst (Ed.), Late Victorian Gothic Tales. Oxford University Press, p. 96-108.

Baldick, Chris. (1987). In Frankenstein's Shadow: Myth, Monstrosity and NineteenthCentury Writing. Clarendon Press.

Bandyopadhyay, Sekhar. (2004). From Plassey to Partition: A History of Modern India. Orient Blackswan Private Limited.

Berkeley, George. (1975). An Essay Towards a New Theory of Vision. In M. R. Ayers (Ed.), Philosophical Works, Including the Works on Vision, pp. 1-59. J. M. Dent.

Bhabha, Homi K. (1994). The Location of Culture. Routledge.

Brewster, David. (1832) Letters on Natural Magic Addressed to Sir Walter Scott, Bart. Harper and Brothers.

Briggs, Julia. (1977). Night Visitors: The Rise and Fall of the English Ghost Story. Faber \& Faber.

Davison, Carol Margaret. (2003). Burning Down the Master's (Prison)-House: Revolution and Revelation in Colonial and Postcolonial Female Gothic. In Andrew Smith and William Hughes (Eds.), Empire and the Gothic: The Politics of Genre. Palgrave 
Macmillan, pp. 136-54.

Dawson, J.E. (October 1886). "Woman in India: Her Influence and Position”. Calcutta Review, 83, pp. 347-70.

Edmundson, Melissa. (2010). Bithia Mary Croker and the Ghosts of India. The CEA Critic 72.2 , pp. $94-112$.

Fink, Bruce. (1997). A Clinical Introduction to Lacanian Psychoanalysis: Theory and Technique. Harvard University Press.

Foucault, Michel. (2006). History of Madness. Routledge.

Freud, Sigmund. (2003). The Uncanny. Penguin Classics.

Frosh, Stephen. (September 2012) Hauntings: Psychoanalysis and Ghostly Transmission. American Imago, Vol. 69, No. 2, pp. 241-264.

Gordon, Avery F. (2008). Ghostly Matters: Haunting and the Sociological Imagination. University of Minnesota Press.

Handley, Sasha. (2007). Visions of an Unseen World: Ghost Beliefs and Ghost Stories in Eighteenth-Century England. Pickering \& Chatto.

Hay, Simon. (2011). A History of the Modern British Ghost Story. London: Palgrave Macmillan.

Kristeva, Julia. (1991). Strangers to Ourselves. Columbia University Press.

Lacan, Jacques. (1989). Ecrits. (Alan Sheridan, Trans.). Routledge.

Lootens, Tricia. (2003). 'Fear of Furniture: Commodity Gothicism and the Teaching of Victorian Literature'. In Diane Long Hoeveler and Tamar Heller (Eds.), Gothic

Fiction: The British and American Traditions. MLA, pp. 148-58.

MacMillan, Margaret. (1988) Women of the Raj. Thames and Hudson.

Marx, Karl. (1977). Capital. In David McLellan (Ed.), Karl Marx: Selected Writings. Oxford University Press.

Merriam, Dr. Garret. (2017). The Philosophy of Horror [YouTube] https://youtu.be/nXOsYchpXq0

Punter, David. (1996). The Literature of Terror: The Modern Gothic. Longman.

Reid, Thomas. (1969). Essays on the Intellectual Powers of Man. MIT Press.

Scott, Sir Walter. (1830). Letters on Demonology and Witchcraft Addressed to J. G. Lockhart, Esq. John Murray.

Sharpe, Jenny. (1993) Allegories of Empire: The Figure of Woman in the Colonial Text. University of Minnesota Press.

Smajić, Srdjan. (2010). Ghost-Seers, Detectives, and Spiritualists: Theories of Vision in Victorian Literature and Science. Cambridge University Press.

Smith, Andrew. (2010). The ghost story, 1840-1920. Manchester University Press.

\section{Bio-note}

Debarghya Ganguli pursued his M. Phil at the University of Calcutta and is a SACT at Acharya Jagadish Chandra Bose College, Kolkata. He has been a visiting lecturer at multiple UG and PG institutions including Bagbazar Women's College, Bhawanipore Educational Society College, Vidyasagar College and Acharya Prafulla Chandra College. His areas of interest are T. S. Eliot, Modern and Postmodern Theatre, Romantic Poetry, and Bengal Renaissance. His poems have been published in various anthologies. His volume of poetry "Fables of Fibonacci" is under publication.

Email Id: dgconcord@gmail.com 